\title{
СПИСОК РАДИОУГЛЕРОДНЫХ ДАТИРОВОК ИНСТИТУТА ГЕОЛОГИИ АН ЭССР. ІІ*
}

В настоящем списке приводятся датировки, выполненные в Институте геологии АН ЭССР в 1973 г. Эталоном современного углерода служит «пятикратный стандарт». Датировки рассчитаны исходя из значения периода полураспада ${ }^{14} \mathrm{C}$, равного $5568 \pm 30$ годам. За начало принят 1950 г. Смонтирована и налажена двухканальная сцинтилляционная установка. Дополнительно к свинцовой защите применено защитное кольцо из 17 счетчиков MC-6. Амплитуда импульсов и режим работы схемы подобраны таким образом, чтобы при одновременном срабатывании счетчиков защитного кольца и рабочего детектора на выходе схемы антисовпадений импульсов не возникало. Такая защита позволила снизить общий фон на $20-40 \%$ и улучшить его стабильность.

$\mathrm{T} \ln -46$

ушер

$8025 \pm 95$

Торф из морских осадков дистального склона напорной морены ледника Ушер (см. сообщение 1), о. Западный Шпицберген, восточное побережье бухты Мон. Высота террассы 22 м над уровнем моря. Образец отобрал в 1966 г. и представил Л. С. Троицкий (Институт географии АН СССР = Ин-т геогр.).

Tln-48

Млелес-С ала

$\geqslant 45500$

Растительные остатки из-под гравия и алеврита. Обнажение на правом берегу р. Неман в г. Друскининкай (ЛитССР). Образец отобрали с глубины 185-190 см в 1972 г. Я.-М. Пуннинг, Р. Раямяэ и Л. Смирнова (Институт геологии АН ЭССР $=$ ИГ).

\section{Серия Колешки}

Разрез Колешки 1 находится около 1 км ниже по течению р. Ваги - притока р. Северной Двины (Архангельская область) от села Колешки, на правом берегу реки.

Описание разреза

0-1 300 cм - мелко- и среднезернистые пески;

1 300-1 320 см - мелкозернистый песок, насыщенный раковинами моллюсков;

1320 -1 335 см - мелкозернистый серо-желтый песок с прослойками лимонитизированного песка;

1 335-1 585 см - пелит с прослойками песка. В нижней части прослойки торфа мош ностью $0,5-2,0 \mathrm{cM}$;

1.585-1 $650 \mathrm{~cm}$ - алевритовый песок;

$1650-1670 \mathrm{cM}$ - мелкозернистый песок с раковинами моллюсков:

$1670-1880$ см - мелкозернистый серый песок;

урез реки.

* Сообщенне 1 см. «Изв. АН ЭССР. Хим. Геол.», 1974, 23, № 1, 65-71. 
Образцы отобрал в 1972 г. Я.-М. Пуннинг (ИГ).

Tln-52

Колешки 1

$31900 \pm 380$

Створки раковин моллюсков с глубины $1300-1320 \mathrm{cs}$.

$\mathrm{T} \ln -49$

Колешки 1

$37135 \pm 450$

Тростниковый торф с глубины 1535-1537 см.

Tln-71

Колешки 1

$\geqslant 49100$

Гипновый торф с глубины $1547-1550 \mathrm{cs}$.

$\operatorname{Tln}-63$

Колешки 2

$36500 \pm 700$

Торф из разреза около 300 м выше по течению р. Ваги от разреза Колешки 1 (см. Tln-49, 52, 71). Слой торфа мощностью около 40 cм залегает над пелитом на высоте 260-300 cм от уровня реки и покрыт мелкозернистыми песками мощностью около $12 \mathrm{~s}$. Образец отобран Я.-М. Пуннингом из верхней части слоя $(270-275 \mathrm{~cm})$.

$\mathrm{T} \ln -50$

Кр асная Горка

$38300 \pm 1400$

Гипновый торф из обнажения на левом берегу р. Днепра у г. Рогачев (БССР). Линза старичных гиттий и торфа мощностью 30 см залегает в толще аллювиальных песков на глубине $600 \mathrm{~cm}$. Возрасты серий образцов с разных глубин органогенной линзы в пределах 30000-46000 лет (Вознячук, Арсланов, 1971). Образец отобрали в 1972 г. Я.-М. Пуннинг, Р. Раямяэ, Л. Смирнова (ИГ).

Tln-51

Черный берег

$\geqslant 46000$

Торф из обнажения на правом берегу р. Западной Двины у границы г. Сураж (БССР). Над торфом залегает морена мощностью 18 м. Образец отобрали в 1972 г. Я.-М. Пуннинг, Р. Раямяэ, Л. Смирнова (ИГ).

Tln-55

Большая Л агорта

$3300 \pm 110$

Торф из древнеозерных отложений в верховьях р. Большая Лагорта, Полярный Урал (см. сообщение 1). Образец отобрал с глубины 60-68 см в 1972 г. и представил Л. С. Троицкий (Ин-т геогр.).

TIn-54

Большая Л агорта

$4540 \pm 60$

Торф из древнеозерных отложений в верховьях р. Большая Лагорта, Полярный Урал (см. сообщение 1). Образец отобрал с глубины 140-145 см в 1972 г. и представил Л. С. Троицкий (Ин-т геогр.).

Tln-56

Малая Х ад ат а

$5680 \pm 120$

Торф с заболоченного днища долины оз. Малая Хадата, Полярный Урал. Глубина залегания датированного слоя 45-50 см от поверхности торфяника. Общая мощность торфа $160 \mathrm{~cm}$, внизу суглинки видимой мощностью $120 \mathrm{~cm}$. Образец отобрал в 1972 г. и представил Л. С. Троицкий (Ин-т геогр.).

Tln-64

Малая Хадата

$6315 \pm 70$

То же, что Tln-56. Глубина отбора образца 95-100 cм от поверхности торфяника. Образец отобрал в 1972 г. и представил Л. С. Троицкий (Ин-т геогр.).

Tln-53

Малая Хадата

$5590 \pm 50$

То же, что Tln-56. Глубина отбора образца 155-160 см от поверхности торфяника. Образец отобрал в 1972 г. и представил Л. С. Троицкий. Полученный возраст явно занижен.

$\operatorname{Tln}-86$

Малая Х ад ата

$7960 \pm 100$

То же, что Tln-56. Повторный образец из слоя 155-160 см (см. Tln-53). Образец отобрал в 1973 г. и представил Л. С. Троицкий (Ин-т геогр.). 
Tln-57

Е нга

$3480 \pm 60$

Остатки древесины из обнажения у р. Енга, Полярный Урал. Описание древнеозерных отложений (по Л. С. Троицкому) : суглинки 0-190 см; галечники с остатками древесины 190-220 см; суглинки 220-320 см; глина 320-365 см; уровень реки. Образец отобрал в 1972 г. с глубнны 200 см и представил Л. С. Троицкий (Ин-т геогр.).

$\operatorname{Tln}-58$

Силла

$8770 \pm 120$

Сильно разложившийся древесный торф из разреза Силла в пределах возвышенности Карула (Южная Эстония). Образец отобран из межозной впадины из базального слоя болотных отложений. Образец отобрала с глубины 390-400 cм в 1972 г. Р. Қарукяпп (ИГ).

$\operatorname{Tln}-59$

Куйгли

$8865 \pm 70$

Сильно разложившийся тростниковый торф из разреза Куйгли в пределах возвышенности Карула (Южная Эстония). Мощность болотных отложений 265 см в замкнутом понижении оза. Образец отобрала с глубины 250-265 см в 1972 г. Р. Карукяпп (ИГ).

TIn-60

Еловец

$1270 \pm 70$

Древесный уголь из культурного слоя стоянки Еловец на правом берегу р. Онеги напротив д. Шабеньга (Архангельская область). Глубина залегания культурного слоя 35-80 cм. Слой прослеживается на всем протяжении обнаженной части берегового обрыва $(250-300$ м). Образец отобрала в 1971 г. и представила Э. И. Девятова (Ин-т геологии Карельского филиала КФ АН СССР).

Tln-61

Ал а со о

$2770 \pm 50$

Тростниковый торф из разреза болота Аласоо, западный берег Чудского озера около г. Калласте (см. сообщение 1). Глубина отбора образца 141-144 cм. По споровопыльцевым данным Р. Пиррус, торф накопился в переходное время SA1-SA2. Образцы отобрали в 1971 г. и представили Ю. Паап и Р. Пиррус (ИГ).

Tln-62

Ky precoo

$865 \pm 80$

Тростниковый торф из лагунных отложений в восточной части о. Хийумаа. Возраст определяет начало заболачивания лагуны. По данным спорово-пыльцевого анализа Х. Кессел, образец относится к Іа фазе развития лесов. Глубина отбора образца 140150 см. Образец отобрали в 1971 г. и представили Х. Кессел (ИГ) и У. Сепп (Ботанический сад АН ЭССР).

Tln-65

Паливере

$8640 \pm 70$

Древесный торф из-под отложений Анцилового озера около ж/д станции Паливере (Хаапсалуский р-н). Абсолютная высота подножия берегового вала 32 м. Мощность органогенного слоя 25 см. Спорово-пыльцевой анализ выполнила Х. Кессел. Образец относится к VIII фазе развития лесов. Образец отобрал в 1972 г. и представил Ю. Паап (ИГ).

Tln-66

Кыду

$8480 \pm 90$

Древесный торф из-под берегового вала Анцилового озера, в 20 км северо-восточнее г. Пярну. Абсолютная высота подножия берегового вала 13,5 м. Образец отобран из верхней части органогенного слоя мощностью $30 \mathrm{~cm}$. По данным спорово-пыльцевого анализа X. Кессел, образец относится к VIII фазе развития лесов. Образец отобрала в 1971 г. и представила Х. Кессел (ИГ).

TIn- 67

Перв вома йски ий

$\geqslant 37000$

Обнажение на левом берегу р. Северной Двины, около 1,5 км вверх по течению от пос. Первомайский (Архангельская обл.). Описание разреза: мелкозернистый песок $300 \mathrm{~cm}$; серый алеврит $50 \mathrm{~cm}$; песок, слегка лимонитизированный $500 \mathrm{~cm}$; сфагновый торф $70 \mathrm{~cm}$; алеврит с древесными остатками $50 \mathrm{~cm}$; мелкозернистый песок $120 \mathrm{~cm}$; гли- 
на, урез реки. Образец отобран из верхней части сфагнового торфа в 1971 г. Я.-М. Пуннингом (ИГ).

$\operatorname{Tln}-68$

Ш а пі у ров о

$31550 \pm 350$

Растительные остатки на правом берегу р. Каспля у д. Шапурово близ г. Сураж (БССР). В расчистке обнажаются сверху вниз: озерно-аллювиальные отложения, супеси и ленточные глины; морена; суглинки с криотурбациями; алевриты; супеси с растительными остатками. Образец отобран с глубины $1600 \mathrm{~cm}$ от дневной поверхности. В радиоуглеродной лаборатории ЛГу получены возрасты $29150 \pm 850$ (ЛУ-78А) и $36400 \pm 800$ (ЛУ-78Б) (Вознячук, 1972). Образец отобрали в 1972 г. Я.-М. Пуннинг, Р. Раямяэ и Л. Смирнова (ИГ).

Tln-69

Сн ай гупеле

$42600 \pm 600$

Гиттия из разреза на правом берегу р. Снайгупеле - левого притока р. Нямунас, в 2 км ниже г. Друскининкай (ЛитССР). Датируемый комплекс покрыт песками (180 cм) и мореной $(260 \mathrm{~cm})$. По данным О. П. Кондратене (1973), подморенные отложения накапливались во время межледниковья, палеогеографические условия которого отличаются от условий во время мяркинского (рисс-вюрмского) межледниковья. По мнению О. П. Кондратене, отложения накапливались до рисс-вюрмского межледниковья. Образец отобрали в 1972 г. Я.-М. Пуннинг, Р. Раямяэ и Л. Смирнова (ИГ).

Tln-70

Конопки Лесьне

$39530 \pm 450$

Торф из разреза Конопки Лесьне близ г. Ломжа в северо-восточной части Польской Народной Республики. Торф покрыт песками. По данным 3. Боровко-Длужакова (Borowko-Dluzakowa, Halicki, 1957; Borowko-Dluzakowa, 1973), межледниковые отло. жения представлены двумя термическими оптимумами и накапливались во время эмского межледниковья. Глубина отбора 315-345 см. Образец представил в 1971 г. Э. Мойский (Ин-т геол., Варшава).

Tln-72

Ломжа

$\geqslant 45400$

Торф из разреза Ломжа у г. Ломжа в северо-восточной части Польской Народной Республики (см. Tln-70). Образец из межледниковых отложений отобрал с глубины 730-760 см и представил в 1971 г. Э. Мойский (Ин-т геол., Варшава).

Tln-73

Я нони с

$37900 \pm 300$

Известковый торф из разреза у с. Янонис Аникшчяйского р-на (ЛитССР). В обнажении залегают сверху вниз моренные суглинки, гумусированные пески, местами переходящие в торфозем, известковый туф родникового генезиса, мелкозернистые пески. В радиоуглеродной лаборатории ЛИТНИГРИ датированы верхний слой известкового туфа в $22700 \pm 360$ (Vs-39), средний слой $24800 \pm 450$ (Vs-40) и нижний слой $27200 \pm 400$ (Vs-41) лет (Вайтонис и др., 1972). Образец отобрали из верхней части туфа в 1971 г. Я.-М. Пуннинг, Р. Раямяэ, Л. Смирнова (ИГ).

Tln-74

Га й люн а й

$\geqslant 32000$

Межледниковые отложения на левом берегу р. Нямунас околю 2,5 км от г. Друскининкай (ЛитССР). Описание разреза: песок 300 см; серая морена $120 \mathrm{~cm}$; алеврит, содержащий в верхней части створки раковин моллюсков, в нижней части - остатки древесины $200 \mathrm{~cm}$; урез реки. Образец отобран из нижней части алеврита в $1971 \mathrm{r}$. Я.-М. Пуннингом, Р. Раямяэ, Л. Смирновой (ИГ).

Tln-75

Керкидон

$8525 \pm 85$

Обуглившиеся остатки растений из озерно-аллювиальных отложений второй надпойменной террасы правого берега р. Керкидон (Юго-Восточная Фергана). Образец отобрали с глубины 850 см от поверхности в 1972 г. и представили Г. Н. Пшенин в Л. Р. Серебрянный (Ин-т геогр.). 
Обуглившиеся остатки растений со второй надпойменной террасы правого берега p. Керкидон (см. Tln-75). Образец отобрали с глубины 700 см от поверхности в 1972 г. и представили Г. Н. Пшенин и Л. Р. Серебрянный (Ин-т геогр.).

Tln-77

Р а й бола

$\geqslant 49000$

Древесный торф из обнажения у д. Райбола, левый берег р. Ваги (Архангельская область). Слой торфа залегает в песках на высоте $5 \mu$ от уровня реки. Над песками залегает морена. Образец отобрала в 1972 г. и представила Э. И. Девятова (Ин-т геол. КФ AH CCCP).

Tln-78

Cопка

$8245 \pm 80$

Моховой торф у д. Мечта на левом берегу р. Северной Двины (Архангельская область). Линза торфа залегает в аллювиальных отложениях под глинистыми отложениями. Образец отобрали в 1972 г. Я.-М. Пуннинг и Э. И. Девятова (ИГ, Ин-т геол. КФ $\mathrm{AH}$ CCCP).

\section{Серия Систа-Палкино}

Разрез находится на правом берегу р. Систа у с. Палкино (Ленинградская область). Описание разреза: разнозернистые пески 0-270 см; древесный торф 270-275 см; пески 275-285 см; древесный торф с прослойками гипнового торфа 285-325 см; алеврит $325-375$ см; гравелистая морена $375-475$ см; кембрийские отложения. Образцы отобрали в 1973 г. Т. Какум, Я.-М. Пуннинг и Р. Раямяэ (ИГ).

Tln-79

Систа -П алкино

$6000 \pm 80$

Древесный торф с глубины 270-275 см. По данным спорово-пыльцевого анализа Х. Кессел, торф погребен во время литориновой трансгрессии.

$\mathrm{T} \ln -80$

С и с т а - П а лкино

$6570 \pm 80$

Древесный торф с глубины 285-290 cм.

Tln- 81

С ист а - П лкино

$7980 \pm 90$

Древесный торф с глубины 320 - 325 см. Торфообразование началось вскоре после кульминации анциловой трансгрессии.

TIn-82

Ч а рт а ксай

$3995 \pm 70$

Торф со второй надпойменной террасы левого берега р. Чартаксай, в 20 км к сереро-востоку от г. Наманган (Северная Фергана). Торфяной слой залегает в глинах. покрытых галечником. Образец отобрал в 1972 г. и представил Г. Н. Пшенин (Ин-т геогр.).

$\mathrm{T} \ln -83$

Малая $\mathrm{X}$ а дат а-1

$6280 \pm 70$

Образец из торфяного бугра у оз. Малая Хадата, Полярный Урал. Мощность торфа $200 \mathrm{~cm}$. Под торфом залегают суглинки видимой мощностью $150 \mathrm{~cm}$. Образец отобрал с глубины 40-45 см в 1973 г. Л. С. Троицкий (Ин-т геогр.).

Tln-84

Мал ая Х ад а т а-1

$6745 \pm 70$

Образец нз торфяного бугра у оз. Малая Хадата, Полярный Урал (см. Tln-83). Образец отобрал с глубины 95-100 см в 1973 г. Л. С. Троицкий (Ин-т геогр.).

Tln-85

$\mathrm{M}$ ал а я $\mathrm{X}$ ад а т а-1

$8670 \pm 100$

Образец из торфяного бугра у оз. Малая Хадата, Полярный Урал (см. Tln-83). Образец отобрал с глубины $175-200 \mathrm{cM}$ (базальный слой торфяника) в 1973 г. Л. С. Троицкий (Ин-т геогр.) . 


\section{Л И Т Е Р А Т У Р A}

В айтонис В., Клим а аускас А., Кудаб а Ч., Шулия К. 1972. О позднеантропогеновых межморенных образованиях у села Янонис. Liet. TSR Aukštuju mokykly Mokslo darbai, Geogr. ir geol., 9, 147-150.

В озняч ук Л. Н., А р слано в Х. А. 1971. К палеогеографии и геохронологии эпохи валдайского оледенения на территории Белоруссии. В сб.: Хронология ледникового века. Л.

В озн я ч ук Л. К. 1972. Возраст максимальной стадии валдайского оледенения на северо-западе СССР и основные фазы деградации ледника. В сб.: Вопросы четвертичной геологии, VI. Рига.

К о нд р а ен е О. П. 1973. О типах пыльцевых диаграмм мяркинского (микулинского, рисс-вюрмского) межледниковья Литвы и вопрос их одновозрастности. В сб.: Палинология плейстоцена и плиоцена, $M$.

Borowko-Dluzakowa Z. 1973. New localities with Eemian flora in the Polish lowland. Palynology of Pleistocene and Pliocene. Proceedings of the 3rd International Palynological Conference. $M$.

Borowko-D l u zakowa Z., Ha licki B. 1957. Interglacjalu Suwalszczyzny i terenow sasiednich. Acta geol. polon., 7, № 4.

Ннститут геологии

Академии наук Эстонской ССР
Поступила в редакцию $7 / \mathrm{V} 1974$

\section{J.-M. PUNNING, T. KAKUM, R. RAJAMÄE}

\section{ENSV TA GEOLOOGIA INSTITUUDIS RADIOSUSINIKU MEETODIL DATEERITUD PROOVIDE NIMISTU. II}

Artiklis esitatakse ENSV TA Geoloogia Instituudis 1973. aastal radiosüsiniku meetodil dateeritud proovide nimistu, mis sisaldab 40 proovi vanuse. Vanuste arvutamisel on lähtutud ${ }^{14} \mathrm{C}$ poolestusajast $5568 \pm 30$ aastat, vanus on antud alates 1950 . aastast.

\section{J.-M. PUNNING, T. KAKUM, R. RAJAMÄE}

\section{LIST OF SAMPLES DATED BY THE RADIOCARBON METHOD AT THE INSTITUTE OF GEOLOGY OF THE ACADEMY OF SCIENCES OF THE ESTONIAN SSR. II}

The following $\|$ ist includes ${ }^{14} \mathrm{C}$ dates calculated at the Institute of Geology of the Academy of Sciences of the Estonian SSR in 1973. All radiocarbon dates are calculated (from the year 1950 ) with ${ }^{14} \mathrm{C}$ half-life of $5568 \pm 30$ years. 